\title{
TÓTH GÉZA: AZ AUTÓPÁLYÁK SZEREPE A REGIONÁLIS FOLYAMATOKBAN
}

\author{
(Központi Statisztikai Hivatal, Budapest, 2005, 128 o.)
}

\section{LIESZKOVSZKY JÓZSEF}

Mindig öröm számomra olyan témával kapcsolatos múvet olvasni, amelyről még nem készült részletes és szabatos tanulmány. Ilyen Tóth Géza doktori disszertációjának olvasható kivitelben való megjelenése. „Az autópályák szerepe a regionális folyamatokban" az első olyan magyar nyelven megjelent nagyobb lélegzetü tanulmány, amelyben az autópályák és a regionális folyamatok együtt szerepelnek.

Igen szimpatikus számomra az, hogy már a 2. fejezet elején megfogalmazódik az a fontos megállapítás, hogy a közlekedés csak akkor tudja a gazdaságot egy adott területen dinamizálni, ha a gazdaság ahhoz megfelelő színvonalon van. Azaz az infrastruktúra-fejlesztések igen fontosak a periférikus térségek felzárkóztatása során, de ezek önmagukban hatástalanok. Kellő eredmény csak abban az esetben érhető el, ha hozzá más területfejlesztési eszközt is alkalmazunk.

A szerző elsőként az autópályák gazdasági hatásait elemzi. Ezek az adott térségekben igencsak összetett folyamatként jelentkeznek - megemlíthető itt például a megvalósíthatósági tanulmányok hatásai, munkanélküliség csökkenése vagy a fogyasztási kiadások hatásai - $\mathrm{s}$ mindenféleképp megemlíthető, hogy egy autópályának a gazdaságélénkítő hatásai akkor is jelentősek, ha annak forgalmi hatása elmarad a várakozásoktól (BK). Egy új autópálya előnyeiböl leginkább a szállítást végző cégek profitálnak, s akkor lehet igazán nagy befektetésekre számítani, ha ipari parkok kialakításával teremtik meg a zöldmezős vállalatoknak a megtelepedés lehetöségét. Általában elmondható az, hogy az autópálya-építésekkel kapcsolatos hatások inkább pontszerủen jelennek meg, így folyamatosan szétterülő településfejlődési hatásokról ezen esetben nem beszélhetünk.

A vállalkozások telephelydöntéseiben is fontos szerepet játszik az autópálya léte vagy nem megléte, azonban ez térségenként eltérỏ súllyal szerepel. Egyes területek számára már nem jelent versenyelőnyt az autópálya-épités, hazánkban viszont még mindig az egyik legfontosabb területfejlesztési feladat a régióközpontok bekapcsolása az autópálya-hálózatba.

Ágazati szinten a feldolgozóipari vállalkozások (ezen belül is a gépipar) számára a legfontosabb az autópályához való hozzáférés. Egy holland felmérés alapján kimutatták, hogy az autópálya-felhajtókhoz való közelség a vállalkozásoknak egyik legfontosabb telephelyválasztási szempontja. Hazánkban az M0-ás mentén található vállalkozások körében végeztek kérdöíves felmérést, amely kimutatta, hogy ezen cégek java része könnyen mobilizálható, kiskereskedelemmel foglalkozik, s nem tervez hosszú távra. 
A szerző külön fejezetrészt szentel az autópályák és a városi közlekedés kapcsolatának. Az autópályák sok esetben egyes városrészek teljes szerkezeti módosulását eredményezik, mint ahogy tette ezt az M3-as autópálya a föváros XV. kerületében, Rákospalotán.

$\mathrm{Az}$ autópálya és az adott társadalom kapcsolata másképp alakult az USA-ban, mint Kelet-Közép-Európában. Amíg az Egyesült Államokban föleg a legfelsőbb rétegek költöznek ki a szuburbiákba - kihasználva az autópályák adta elönyöket -, addig térségünkben ezen társadalmi csoporton kívül az alacsony keresetü és végzettségủ rétegek is kiköltöztek az agglomerációba, azonban számukra az autópálya elhelyezkedése egyáltalán nem fontos lakóhely-választási tényezö.

A szerző a szuburbanizáció nyomán létrejött új és fontos városképző folyamatot is bemutat, mégpedig az edge city, azaz peremváros jelenséget. A peremvárosok a szuburbia olyan alközpontjai, amelyek szorosan kapcsolódnak az autópályákhoz, illetve azok csomópontjaihoz. Tehát elmondható, hogy a szuburbanizáció és az autópálya-fejlesztés egymással kölcsönhatásban álló folyamatok.

A 3. fejezetben az autópályák és a gazdaság közötti kapcsolatról esik szó. A kapcsolatok szorosságának vizsgálata során megállapítható, hogy létezik kapcsolat a közúti infrastruktúra, valamint a területi fejlettség között, továbbá a szerző által elvégzett kutatások bizonyítják, hogy leginkább megyei szinten érezhetök a gyorsforgalmi úthálózat fejlesztésének hatásai.

Egyes gazdasági mutatók tekintetében az autópályával rendelkező kistérségek a kitüntetett Budapestnél is sokkal jobb dinamikával rendelkeznek. Ezekben a térségekben nőtt meg az aktív korúak, valamint az épített lakások száma is, továbbá a regisztrált munkanélkuuliek száma ezen térségekben csökkent a leginkább. A térségek vándorlási egyenlege már régóta pozitív.

A 4. fejezetben az északkelet-magyarországi autópálya-fejlesztéseket mutatja be a szerző három megye, Borsod-Abaúj-Zemplén, Hajdú-Bihar és Szabolcs-SzatmárBereg példáján, melyek a legnagyobb strukturális problémával küzdő térségek. Ezen periférikus, tartós válságban található kistérségek számára az autópálya-építés önmagában nem jelent fejlödést, hiszen az alapja sincsen meg a további fejlődésnek. Azonban megállapítható ezzel szemben az, hogy az autópályák kiépítését részben indokolja a jelenlegi forgalom nagysága is, s a közeljövőben várható folyamatok ezt még jobban megalapozzák.

Összegezve megállapitható hogy a szerzö kutatásai igazolták a közlekedésfejlesztés és a területi folyamatok közötti kapcsolatot, tehát a településfejlesztés sem hagyhatja figyelmen kívül az autópálya-építések során elkezdődő folyamatokat. 